\title{
LOSY SAKRAMENTARZA TYNIECKIEGO PODCZAS II WOJNY ŚWIATOWEJ
}

Tematem artykułu są losy jednego z najcenniejszych i najstarszych średniowiecznych zabytków na ziemiach polskich - Sakramentarza tynieckiego. Losy jedenastowiecznego rękopisu na przestrzeni prawie dziesięciu stuleci są niezwykle ciekawe i ukazują, jak kodeks wpisał się w dzieje Polski. Dramatyczny, nie tylko dla rękopisu tynieckiego, był czas drugiej wojny światowej, kiedy to ludzie z narażeniem życia starali się uratować najbardziej wartościowe zabytki polskiej kultury. Znamienne jest, że dzieje rękopisu tynieckiego przedstawiają losy wszystkich ocalałych z pożogi wojennej bezcennych ksiąg rękopiśmiennych i drukowanych. Sakramentarz tyniecki jest zabytkiem, który nie doczekał się szerokiej literatury na swój temat, zwłaszcza poruszającej zagadnienie jego historii. Nie powstało opracowanie, które przedstawiałoby losy Sakramentarza w ujęciu chronologicznym. Informacje dotyczące kodeksu znajdują się w wielu pozycjach dotyczących różnej tematyki, w tym w albumach z zakresu historii sztuki czy monografiach dotyczących Biblioteki Ordynacji Zamoyskiej, gdzie omawiany jest zazwyczaj jako przykład sztuki iluminatorskiej.

Wykorzystane w niniejszym opracowaniu źródła obejmują przede wszystkim wspomnienia oraz dokumenty dotyczące drugiej wojny światowej. Są to relacje osób, które zetknęły się z Sakramentarzem tynieckim, zebrane w dwóch tomach Walki o dobra kultury. Warszawa I939-I945 ${ }^{1}$ oraz we Wspomnieniach o Bibliotece Narodowej ${ }^{2}$. Podstawowym źródłem są relacje Bogdana Horodyskiego ${ }^{3}$, który w czasie wojny był naocznym świadkiem i zaangażowanym uczestnikiem zabiegów mających na celu ochronę rękopisu. W opracowaniach zdecydowanie najczęściej poruszane były przede wszystkim walory estetyczne kodeksu: misterne miniatury, liczne inicjały i bordiury. Podejmowane były w nich także starania, aby wyjaśnić okoliczności, w jakich zabytek pojawił się w klasztorze benedyktynów w Tyńcu. Są to zazwyczaj skrótowe informacje podawane wraz z charakterystyką innych cennych zabytków z tej epoki.

Sakramentarz tyniecki jest jednym z nielicznych zachowanych kodeksów w zbiorach polskich, co do których istnieje pewność, że znajdowały się na ziemiach polskich już we

\footnotetext{
* Katarzyna Sijka, absolwentka Wydziału Nauk Historycznych i Społecznych Uniwersytetu Kardynała Stefana Wyszyńskiego, doktorantka w Instytucie Nauk Historycznych. Jej zainteresowania to historia książki i bibliotek oraz historia kultury i literatury głównie w XIX wieku. E-mail: sijkakatarzyna@gmail.com.

Walka o dobra kultury. Warszawa 1939-1945, t. 1-2, red. S. Lorentz, Warszawa 1970.

Wspomnienia o Bibliotece Narodowej, przedm. A. Kłossowski, Warszawa 1995.

B. Horodyski, Biblioteka Ordynacji Zamoyskiej w latach wojny, Warszawa 2005.
} 
wczesnym średniowieczu. Sakramentarz powstał około Io60-I070 r. w diecezji kolońskiej4. Na miejsce oraz czas wykonania kodeksu wskazują styl, kompozycja i technika dekoracji, jak również imiona świętych pojawiające się w kalendarzu ${ }^{5}$. Z okresu od XII aż do początku XIX w. jest niewiele informacji na temat losów Sakramentarza tynieckiego. Początkowo, co najmniej do XIII stulecia, używany był podczas liturgii, z czasem doceniono wartość kodeksu i traktowano księgę jako cenny zabytek. Znany jest epizod z XVII w., dotyczący kradzieży rękopisu, o którym informuje nota na jego pierwszej stronie. W I8I4 r. Stanisław Kostka Zamoyski zakupił księgę za Iooo złotych polskich ${ }^{6}$. Cztery lata później umieścił kodeks w Bibliotece Ordynacji Zamoyskiej w Warszawie (dalej: BOZ), w której był jednym z najstarszych i najcenniejszych rękopisów. Na tym kończą się wiadomości dotyczące historii rękopisu. Kolejne informacje pojawiają się już w związku z nowym miejscem przechowywania Sakramentarza i pochodzą ze wspomnień bibliotekarzy związanych z BOZ. Dzięki nim można prześledzić losy kodeksu podczas II wojny światowej.

\section{Zarys historii Biblioteki Ordynacji Zamoyskiej w trakcie II wojny światowej}

Zbiory biblioteki rodu Zamoyskich były zaliczane do najcenniejszych w XIX w. w Królestwie Polskim ${ }^{7}$ W dwudziestoleciu międzywojennym liczyły ponad I20 tysięcy woluminów, a biblioteka była siódmą co do wielkości w Warszawie. W I929 r. stanowisko dyrektora biblioteki powierzono profesorowi Ludwikowi Kolankowskiemu (I882-I956) ${ }^{8}$. W maju I939 r. zarząd nad ordynacją objął Jan Zamoyski (I9I2-2002)9. Od początku miał trudne zadanie do wykonania, musiał zabezpieczyć zbiory ordynacji przed zbliżającą się wojną. We wspomnieniach Bogdana Horodyskiego ${ }^{\mathrm{IO}}$, naocznego świadka wydarzeń, znajduje się opis tych

4 E. Potkowski, Książka rękopiśmienna w kulturze Polski, Warszawa 1984, s. 28; zob. W. Podlacha, Historia malarstwa w Polsce, t. 1: Od średniowiecza do wieku XVIII-go, cz. 1: Malarstwo średniowieczne, Lwów 1913 , s. 41.

5 J.W. Boguniowski, Rozwój historyczny ksiag liturgii rzymskiej do Soboru Trydenckiego i ich recepcja w Polsce, Kraków 2001, s. 71.

6 Stanisław Kostka Zamoyski zapisał te informacje na jednej z pierwszych stron kodeksu: „Od naydawniejszych czasow ten mszał znaydował się w Opactwie Tynieckim. Jest to dzieło wieku 9go lub 10go, lecz bardziey ma podobieństwo z pismem y rysonkami 9go wieku. W potrzebie reparacyi Kościoła, wystawionem byl na sprzedaż, dałem za niego złotych tysiąc w Krakowie Roku 1814. Składam go do Bibliotheki Ordynacyi Zamoyskiey, ktorego zbioru będzie może nay starożytnieyszym zabytkiem. Warszawa dnia 24 Lutego 1818 Roku. Stanisław Ordynat Zamoyski mp"; zob. [Sacramentarium Tinecense], sygn. Rps BOZ 8.

7 H. Łaskarzewska, Bogdan Horodyski - kronikarz dziejów Biblioteki Ordynacji Zamoyskiej w czasie okupacji (1939-1945), w: B. Horodyski, Biblioteka Ordynacji Zamoyskiej w latach wojny, Warszawa 2005, s. 5.

8 Ludwik Kolankowski (1882-1956), historyk i bibliotekarz. Od 1929 roku był dyrektorem Biblioteki Ordynacji Zamoyskiej. Dzięki niemu biblioteka stała się sprawnym ośrodkiem naukowym. Od 1939 roku ratował dobra biblioteczne, dzięki niemu ocalał m.in. Sakramentarz tyniecki, a Biblioteka stała się tajnym ośrodkiem naukowym w Warszawie. Zob. J. Długosz, Kolankowski Ludwik, w: Słownik Pracowników Książki Polskiej, red. I. Treichel, Warszawa-Łódź 1972, s. 428.

9 Jan Tomasz Zamoyski (1912-2002) w latach 1939-1944 był szesnastym (ostatnim) ordynatem Ordynacji Zamoyskiej, podczas drugiej wojny światowej żołnierz AK. Zob. J. Zamoyski, , By pamięć przetrwała ... ”. Rozmowa z senatorem Janem Zamoyskim XVI ordynatem Zamoyskim. Rozmawiała E. Markiewicz, „Biuletyn Informacyjny Biblioteki Narodowej", 1999, nr 2, s. 26-27.

10 Bogdan Horodyski (1904-1965), historyk, bibliotekarz. Od 1932 r. był pracownikiem Biblioteki Ordynacji Zamoyskiej, od 1935 roku był kierownikiem oddziału rękopisów, zastępował dyrektora L. Kolankowskiego. Od 1938 r. gromadził dokumenty dotyczące biblioteki, które uległy zniszczeniu podczas wojny. Po 1945 roku wciąż zajmował się dziejami biblioteki. Od 1945 r. był pracownikiem Biblioteki Narodowej, połączył ocalałe zbiory Biblioteki Narodowej, Biblioteki Ordynacji Zamoyskich oraz Biblioteki Ordynacji Krasińskich. Zob. A. Michalewska, A. Walendowska, Horodyski Bogdan, w: Słownik Pracowników Książki Polskiej, s. 340-341. 
przygotowań: „Przez ostatnie pięć dni sierpnia 1939 roku wrzała w Bibliotece Ordynacji Zamoyskiej gorączkowa i wytężona praca. Alarmujące wieści, pełne niepokoju nastroje, zmuszały do szybkiej decyzji, co z bezcennych zbiorów bibliotecznych zabezpieczyć na wypadek wybuchu wojny i w jaki sposób zabezpieczyć. [...] Kilkanaście skrzyń pomieściło wszystkie cymelia i pergaminy, wybrane rękopisy, inkunabuły i druki XVI wieku oraz najbardziej wartościowe muzealia. Skrzynie te zniesiono do podziemi i zamurowano bez śladu w jednym z dwu wielkich pieców, służących do ogrzewania powietrza pod posadzką sali bibliotecznej”" W jednej z zamurowanych skrzyń znajdował się Sakramentarz tyniecki. Oprócz ochrony zbiorów, starano się jak najlepiej zabezpieczyć sam gmach biblioteki. Okna sali zostały zabite deskami oraz założone workami z piaskiem. Wewnątrz budynku na wypadek pożaru przygotowany był odpowiedni ekwipunek: wiadra z wodą, łopaty i szufle. Do piwnic zniesiono również inwentarze biblioteczne. Reszta zbiorów pozostała na swoim miejscu.

Podczas wojny Biblioteka Ordynacji Zamoyskiej zachowała swoją odrębność i całkowicie polskie kierownictwo ${ }^{12}$. Pozostawała pod zarządem „Generaldirektion Zamoyski”, która mieściła się w Zwierzyńcu koło Zamościa i finansowała zarówno jej utrzymanie jak i personel $^{13}$. Dopiero 30 grudnia I94I r. merytoryczny zarząd nad biblioteką przejęła Biblioteka Państwowa ${ }^{14}$. Było to niekorzystne dla BOZ, dlatego podejmowano starania, aby dwie biblioteki ordynackie: Zamoyskich i Krasińskich, pozostały poza formalnym zarządem Biblioteki Państwowej. Starania podejmował przede wszystkim Józef Grycz's ${ }^{15}$ później przyłączyli się do niego Ludwik Kolankowski i Jan Zamoyski. Osobą odpowiedzialną za podejmowanie takich decyzji był berliński bibliotekarz Gustav Abb ${ }^{16}$ stojący na czele Głównego Zarządu Bibliotek z siedzibą w Krakowie ${ }^{\mathrm{I}}$. Poza tym kierownictwem, nad polskimi bibliotekami istniały dwie formacje, które były odpowiedzialne za grabież polskich dóbr kultury. Pierwszą $\mathrm{z}$ nich był oddział kierowany przez profesora archeologii Petera Paulsena ${ }^{18}$. Oddział został

\footnotetext{
11 B. Horodyski, Biblioteka Ordynacji Zamoyskiej w latach wojny, s. 27.

12 Tamże, s. 16.

13 Tamże, s. 17.

14 Tamże.

15 Józef Grycz (1890-1954), bibliotekarz, organizator nowoczesnego bibliotekarstwa polskiego. Od lipca 1940 r. objął kierownictwo nad Biblioteką Narodową, przekształconą przez okupantów w II Oddział tzw. Staatsbibliothek Warschau. Po powstaniu warszawskim kierował akcją ewakuacyjną ocalonych zbiorów. Zob. H. Więckowska, I. Treichel, Grycz Józef (1890-1954), w: Polski Słownik Biograficzny, t. 9, Wrocław 1960-1961, s. 69-71.

16 Gustaw Abb (1886-1945). Przed wojną pracownik berlińskiej Pruskiej Biblioteki Państwowej, od 1934 roku był dyrektorem Biblioteki Uniwersyteckiej w Berlinie. Od 1933 roku członek NSDAP. W 1. 1937-1942 był przewodniczącym Stowarzyszenia Bibliotekarzy Niemieckich. Od 1 lipca 1940 r. był kierownikiem Głównego Zarządu Bibliotek w Generalnym Gubernatorstwie. Był również dyrektorem Biblioteki Państwowej w Krakowie. Zob. H. Łaskarzewska, Biblioteki warszawskie w latach okupacji..., s. 563.

17 Główny Zarząd Bibliotek został powołany 1 lipca 1940 roku. Na jego czele stanął berliński bibliotekarz Gustaw Abb. 27 lipca tego roku w Warszawie utworzono Bibliotekę Państwową (Staatsbibliothek Warschau), składająca się z dwóch oddziałów. Oddział I został utworzony z Biblioteki Uniwersyteckiej, Oddział II z Biblioteki Narodowej. III Oddział został utworzony w maju 1941 r. i włączono do niego Bibliotekę Ordynacji Krasińskich. Kierownikiem całej Biblioteki Państwowej został wrocławski bibliotekarz Wilhelm Witte. Powołano również tak zwanych mężów zaufania dla poszczególnych oddziałów: dla pierwszego Adama Lewaka, dla drugiego i trzeciego Józefa Grycza. Zob. H. Łaskarzewska, Biblioteki warszawskie w latach okupacji..., s. 538, B. Horodyski, Biblioteka Ordynacji Zamoyskiej w latach wojny, s. 16.

18 Peter Paulsen (1902-1985), profesor prehistorii, prawdopodobnie w 1939 r. został mianowany prof. nadzwyczajnym Uniwersytetu Berlińskiego, członek NSDAP i SS. Zob. A. Mężyński, Kommando Paulsen, październikgrudzień 1939 r., Warszawa 1994, s. 10.
} 
powołany z inicjatywy instytucji naukowej SS Wspólnota Naukowo-Badawcza „Dziedzictwo Przodków” („Das Ahnenerbe”) ${ }^{19}$. Przewodniczącym tej formacji był Heinrich Himmler. Jej głównym zadaniem była konfiskata i wywóz dzieł sztuki do Rzeszy. Drugą grupą była komisja Kajetana Mühlmanna ${ }^{20}$. Działania obu tych grup były dość podobne ${ }^{2 I}$.

Już 25 września 939 r. spłonął Pałac Błękitny. Znajdowała się w nim galeria muzealna oraz nowe pomieszczenia biblioteczne, urządzone przez profesora Tadeusza Korzona ${ }^{22}$, wraz z biurami, czytelnią, katalogiem, zbiorami czasopism, kalendarzy oraz większością rękopisów ${ }^{23}$. Wtedy zniszczeniu uległa prawie cała część zbiorów artystycznych biblioteki ordynackiej, w tym czterysta obrazów i miniatur ${ }^{24}$. Uratowano najcenniejszą część zbiorów, którą złożono w Sali Głównej. Bibliotekarzem, który z poświęceniem własnego życia ratował biblioteczne zbiory, był Bogdan Horodyski. Tak wspomina to wydarzenie: „Na Pałac Błękitny i jego oficyny padło ich [bomb zapalających] około dwudziestu. Pożar wybuchł 25 września w kilku od razu punktach. [...] Bibliotekę ratowało trzech: dyrektor i dwu woźnych - Walczak i Rosadziński. Zdołali jednak zabezpieczyć dach nad głównym budynkiem Biblioteki, mieszczącym najcenniejszy, najstarszy księgozbiór, zdołali wynieść z gabinetu dyrektora ulokowaną tam reprezentacyjną część księgozbioru”². Pożar trwał blisko czterdzieści godzin, w jego trakcie ucierpiał Pałac Błękitny i oficyny od ulicy Żabiej i Placu Bankowego. Horodyski wspomina, że cudem ocalał gmach biblioteczny, zwłaszcza że otaczały go same spalone budynki ${ }^{26}$. Znana jest również notatka przedstawiająca niemiecki punkt widzenia na temat strat biblioteki. Sporządził ją Wilhelm Witte ${ }^{27} 27$ września $^{28}$.

19 B. Horodyski, Biblioteka Ordynacji Zamoyskiej w latach wojny, s. 19.

20 Dowodził nią SS-Standertenfürer Kajetan Mühlmann, który został wysłany w październiku 1939 r. do Generalnego Gubernatorstwa przez Hermanna Göringa, w celu „zabezpieczenia” polskich dzieł sztuki i zabytków kultury. Komisja ta, w przeciwieństwie do Kommando Paulsen, zachowywała pozory legalizmu. Działająca w Warszawie grupa to: Josef Mühlmann historyk sztuki z Salzburga, Anton Kraus, Karl Pollhamwer. Współpracował z nimi Dagobert Frey z Uniwersytetu Wrocławskiego. Wszyscy członkowie byli historykami sztuki i ich zadaniem było wyszukiwanie iluminowanych średniowiecznych rękopisów, inkunabułów. Zob. A. Mężyński, Biblioteki Warszawy w latach 1939-1944, s. 85.

21 A. Mężyński, Kommando Paulsen, październik-grudzień 1939 r., s. 16.

22 Tadeusz Korzon (1839-1918), historyk, od kwietnia 1897 r. był bibliotekarzem w Bibliotece Ordynacji Zamoyskiej. Zob. W. Konopczyński, Korzon Tadeusz Sylwester, w: Polski Słownik Biograficzny, t. 14, Wrocław 19681969, s. 178-181.

23 Biblioteka Ordynacji Zamoyskiej: od Jana do Jana. Przewodnik po wystawie, oprac. T. Makowski, Warszawa 2005, s. 29.

24 A. Lewak, Archiwa i biblioteki Warszawy podczas wojny i okupacji w latach 1939-1945, w: Walka o oświatę, nauke $i$ kulture $w$ latach okupacji 1939-1944. Materiaty z terenu m.st. Warszawy $i$ woj. warszawskiego, oprac. S. Dobraniecki, W. Pokora, Warszawa 1967, s. 684.

25 B. Horodyski, Biblioteka Ordynacji Zamoyskiej w latach wojny, s. 31.

26 Znana jest także relacja T. Makowieckiego z 1944 r. o tym, jak podczas akcji pruszkowskiej po raz pierwszy zobaczył spaloną stolicę: „Biblioteka Ordynacji Zamoyskiej na Żabiej też spalona; ta zbytkowna sala [...] jest pustą, czarną jamą. Ale w piwnicach - są książki, ocalały, i to - najcenniejsze. Wspaniałe brązowe oprawy z wytłokami orłów królewskich: biblioteka Zygmunta Augusta, kilkadziesiąt cieniutkich broszur oprawnych w skórę z włóczniami Zamoyskich: to inkunabuły polskie, krakowskie druki, wśród nich liczne unikaty, kilkanaście rękopisów iluminowanych. [...] Układamy ostrożnie bezcenne druki (może setną część całej Biblioteki), zabijamy skrzynie, numerujemy, spisujemy ogólnie zawartość", T. Makowiecki, W obronie zbiorów bibliotecznych, w: Walka o dobra kultury. Warszawa 1939-1945, t. 2, red. S. Lorentz, s. 246.

27 Wilhelm Witte (1903-1997), absolwent slawistyki na Uniwersytecie Wrocławskim. W 1. 1937-1940 pracował w Bibliotece Uniwersyteckiej we Wrocławiu. Od lipca 1940 roku do lipca 1944 był kierownikiem Biblioteki Państwowej w Warszawie. Zob. H. Łaskarzewska, Biblioteki warszawskie w latach okupacji. Zasady działania, straty księgozbiorów, w: Straty Warszawy 1939-1945. Raport, red. W. Fałkowski, Warszawa 2005, s. 563.

28 ,25.09.1939 spaliło się łącznie 18 pomieszczeń bibliotecznych, w których znajdowały się: pokój dyrekcji, czytelnia, Oddział Czasopism, część rękopisów, 4 sale magazynowe - we wszystkich było ok. 60000 dzieł; spaliły się 
Zbiory biblioteczne znacznie ucierpiały, a wszystkie eksponaty muzealne uległy zniszczeniu. Spłonął nowy magazyn druków, który zawierał około 30 tysięcy tomów, oraz magazyn rękopisów, w którym znajdowało się blisko I0oo skatalogowanych rękopisów i wiele nieskatalogowanych elementów, których liczbę szacowano na 8000-Io0oo jednostek ${ }^{29}$. Horodyski oceniał te straty na $30 \%$ całych zbiorów. Dokładny spis spalonych dzieł opracował w Stratach działu rękopisów Biblioteki Ordynacji Zamoyskiej w latach 1939-I944 ${ }^{30}$.

Niezwykłe poświęcenie dla bibliotecznych zbiorów wykazało wielu jej pracowników, którzy odznaczyli się niebywałym bohaterstwem, kiedy w ekstremalnych warunkach starali się uratować to, co pozostało po pierwszym pożarze. Najwięcej zaangażowania wykazywał dyrektor Kolankowski, który zdobył specjalny dokument Komendy Wojskowej zabraniający ingerencji w zbiory biblioteki ${ }^{31}$. Niedługo po tym wydarzeniu w jej zniszczonym gmachu pojawili się pracownicy Muzeum Narodowego, którzy przeszukiwali zgliszcza w nadziei, że odnajdą wśród nich niezniszczone zbiory.

Do 1944 r. pozostałe zbiory BOZ były starannie przechowywane i opracowywane przez bibliotekarzy. W lipcu tego roku wszystkie zachowane rękopisy zostały przeniesione do piwnic. Podczas powstania warszawskiego gmach biblioteczny uległ kolejnym zniszczeniom. W pierwszych dniach sierpnia do budynku zostały wrzucone przez Niemców granaty zapalające. Pożar pochłonął kilkadziesiąt tysięcy starych druków, atlasów, czasopism, rycin oraz katalogów ${ }^{32}$. Dzięki temu, że Biblioteka Ordynacji Zamoyskiej nie była zależna od bibliotecznego komisarza niemieckiego, jej zbiory nie zostały przeniesione do Biblioteki Ordynacji Krasińskich i nie zostały spalone przez Niemców w październiku 1944 r.33

Zbiory przeniesione w lipcu do podziemi budynku szczęśliwie ocalały. Były to rękopisy oraz druki z XV i XVI w. Po powstaniu warszawskim zostały przewiezione w 85 skrzyniach do Görbitsch, gdzie przejęła je Armia Czerwona i przekazała do Moskwy ${ }^{34}$. Stamtąa częściowo przekazano je z powrotem do Warszawy w $1947 \mathrm{r}^{35}$. Ocalały zbiór przedstawia się następująco: 637 dokumentów pergaminowych, 860 rękopisów z dawnymi sygnaturami, IO2 pudła zawierające korespondencję Zamoyskich, 29 pudeł Tek Górskiego, 33 pudła dissolutów, 2I tomów inwentarzy druków orz kilkanaście woluminów archiwalnych ${ }^{36}$. Porównując to ze stanem sprzed drugiej wojny, Bogdan Horodyski szacował, że zbiór pergaminów ucierpiał w I0 \%, zbiór rękopisów zaś aż w 50\% ${ }^{37}$. Obecnie ustalenia Horodyskiego nie są już aktualne,

wszystkie wartościowe dzienniki i czasopisma, wszystkie heraldyka, biblioteka podręczna czytelni, cały katalog, prawie wszystkie księgi inwentarzowe". Zob. A. Mężyński, Biblioteki Warszawy w latach 1939-1945, Warszawa 2010, s. 61.

29 B. Horodyski, Biblioteka Ordynacji Zamoyskiej w latach wojny, s. 32.

30 Tenże, Straty działu rękopisów Biblioteki Ordynacji Zamoyskiej w latach 1939-1944, w: Straty bibliotek i archiwaliów warszawskich w zakresie rękopiśmiennych źródet historycznych, t. 3, red. P. Bańkowski, Warszawa 1955, s. 327.

31 Tenże, Biblioteka Ordynacji Zamoyskiej w latach wojny, s. 34.

32 H. Łaskarzewska, Biblioteki warszawskie w latach okupacji..., s. 549-550.

${ }^{33}$ Katalog Wystawy Rękopisów i druków wywiezionych przez hitlerowców do Niemiec uratowanych przez Armię Czerwona i przekazanych Polsce przez rząd radziecki, przedm. S. Skrzeszewski, Warszawa 1948, s. 9.

34 B. Horodyski, Zarys dziejów Biblioteki Ordynacji Zamoyskich, w: Studia nad ksiązka poświęcone pamięci Kazimierza Piekarskiego, red. K. Budzyk, A. Kawecka-Gryczowa, Wrocław 1951, s. 296.

35 Tenże, Straty dzialu rękopisów Biblioteki Ordynacji Zamoyskiej w latach 1939-1944, s. 330.

36 Tenże, Zarys dziejów Biblioteki Ordynacji Zamoyskich, s. 296.

37 Tenże, Straty dziatu rękopisów Biblioteki Ordynacji Zamoyskiej w latach 1939-1944, s. 331. 
wiele pozycji powróciło do kraju z wojennej tułaczki. Spisu strat na nowo podjęła się Krystyna Muszyńska w Katalogu rękopisów. Seria III. Zbiory Biblioteki Ordynacji Zamojskiej wydanym w I99I $\mathrm{r}^{38}$.

\section{Jak ratowano Sakramentarz tyniecki?}

Komisja Kajetana Mühlmanna oraz Oddział Paulsena próbowały zdobyć Sakramentarz tyniecki, gdyż zabytek miał dla Niemców dużą wartość z uwagi na miejsce jego pochodzenia. Los Sacramentarium w tym czasie dzielił przede wszystkim Kodeks supraski, który nie wiązał się z niemiecką kulturą, ale miał dużą wartość pieniężną. Ze wspomnień ludzi pracujących w Bibliotece Ordynacji Zamoyskiej wynika, że członkowie tych dwóch organizacji przybyli do niej w tym samym czasie. Często pracownicy nie wiedzieli, kto zarekwirował zbiory. Pisał o tym Józef Grycz w swoich wspomnieniach: „Jakaś tego typu dotychczas nierozpoznana władza skonfiskowała zimą I939 r. około 50 iluminowanych rękopisów średniowiecznych z Biblioteki Zamoyskich, odmawiając wydania kwitu"39. Bogdan Horodyski wspominał, że dwóch oficerów SS, którzy byli członkami Oddziału Paulsena, przyszło do BOZ w listopadzie 1939 r. ${ }^{40}$. Sam Horodyski nie wiedział, że należą oni do tego oddziału. Byli to Emil Augsburg i profesor Heinrich Harmjanz. Niemcy przybyli w konkretnym celu - żądali wydania im trzech najcenniejszych rękopisów: Kodeksu supraskiego, Kodeksu Zamojskiego oraz Sakramentarza tynieckiego. Upatrzone wcześniej przez okupantów kodeksy były zamurowane w piecu. W wyniku tych „odwiedzin” Niemcy zabrali skrzynię z pięćdziesięcioma najstarszymi rękopisami, która została przeniesiona na Aleję Szucha. Peter Paulsen zapisał: „Z uwagi na zniszczenia wojenne budynku Biblioteki istniało duże niebezpieczeństwo ich kradzieży, zwłaszcza że wartościowsze rękopisy zapakowane były w skrzyni łatwej do transportowania"4I. Można stwierdzić, że była to grabież, która miała ochronić zbiory przed kradzieżą.

Bibliotekarz Bogdan Horodyski wspominał, że dwa razy udało się zwieść okupantów, pokazując im skrzynie zawierające inne kodeksy. Jednak Niemcy doskonale orientowali się w zasobach bibliotecznych. Już przed wojną wrocławski profesor Dagobert Frey przeszukiwał zbiory polskie, wtedy też zobaczył dział cymeliów biblioteki ordynackiej. Po raz trzeci nie udało się oszukać Niemców. Horodyski tak opisuje kolejne przybycie okupantów do biblioteki: „Ultimatum postawione przez rabusiów zmusiło wreszcie do wydobycia z podziemi najcenniejszej skrzyni, pełnej iluminowanych rękopisów. [...] Pozostawiono w niej wprawdzie trzy rękopisy znane Freyowi oraz dla niepoznaki - kilkanaście rękopisów iluminowanych i orientalnych, ale mniej cennych. Resztę najokazalszych wyjęto i zastąpiono rękopisami z XVIII i XIX w., mniejszej wartości. Tak przygotowana skrzynia została opieczętowana i zabrana przez gestapowców, a następnie wywieziona do Niemiec 2I listopada I939 r.’’².

\footnotetext{
38 Katalog rękopisów. Seria III. Zbiory Biblioteki Ordynacji Zamoyskiej, t. II, oprac. B. Smoleńska, K. Muszyńska, Warszawa 1991.

39 J. Grycz, Polityka hitlerowska w „, Generalgouvernement”, w: Walka o dobra kultury. Warszawa 1939-1945, t. 2, red. S. Lorentz, s. 451.

40 B. Horodyski, Biblioteka Ordynacji Zamoyskiej w latach wojny, s. 19.

41 Notatka do akt Petera Paulsena [Dotyczy: Zbioru rękopisów z Biblioteki Zamoyskich w Warszawie] Berlin, dnia 18 kwietnia 1941, w: A. Mężyński, Kommando Paulsen, październik-grudzień 1939 r., s. 73-74.

42 B. Horodyski, Straty działu rękopisów Biblioteki Ordynacji Zamoyskiej w latach 1939-1944, s. 330.
} 
W działaniach tych widać starania bibliotekarzy, którzy próbowali ocalić jak najwięcej cennych zabytków, często zmuszeni byli robić to kosztem tych mniej wartościowych. Niemcy potwierdzili odbiór zapieczętowanej skrzyni, która według Wilhelma Wittego zawierała 63 tomy ${ }^{43}$. Heinrich Hermjanz oszacował wartość zagrabionych rękopisów na milion marek niemieckich ${ }^{44}$. Oddzielnie wycenił Kodeks supraski na imponującą sumę czterech do pięciu milionów marek. W Notatce do akt Petera Paulsena dotyczącej rękopisów z Biblioteki Zamoyskich w Warszawie z kwietnia I94I r. szacowana jest również wartość Sakramentarza tynieckiego. Zapisano tam: „Znalazłem przy tym prawie 50o-letni rękopis karoliński, Sacramentarium kytniensis [!], prawdopodobnie reńskiej roboty, który z niemieckiego punktu widzenia oceniłem jako bardziej wartościowy i dlatego również wyjąłem ze skrzyni, którą następnie zapieczętowałem. Oba rękopisy [również Kodeks supraski] włożone zostały do kasety na pieniądze i w dn. I6.I2.I939 r., jako przedmioty dotyczące tajnych spraw Rzeszy, oddane przeze mnie [P. Paulsena] w Głównym Urzędzie Bezpieczeństwa Rzeszy”45.

W notatce z kwietnia I94I r. Paulsen zapisał, że wyjął ze skrzyni Sakramentarz i Kodeks supraski. Jednak na marginesach wspomnianego dokumentu, w dwóch miejscach są notatki informujące, że do Berlina dotarł jedynie Kodeks supraski ${ }^{4}$. Również Bogdan Horodyski przekazuje ${ }^{47}$, że Sakramentarz pozostał w Warszawie, przewieziono go na Aleję Szucha i nigdy nie był wywieziony do Berlina. Trudno zinterpretować te słowa Paulsena, który szczegółowo opisuje sam moment, w którym „odkrył” w skrzyni ten cenny rękopis. Tym bardziej, że w sprawozdaniu ze stycznia I940 r. , które sporządził na ten temat, jest informacja, że: „Wartościowe rękopisy z Biblioteki Zamoyskich umieszczono w skrzyni, opieczętowano i przekazano służbie bezpieczeństwa w Warszawie. Skrzynia zawiera m.in. sławny Codex Suprasiliensis, najstarszy i najbardziej znany rękopis starosłowiański, którego wartość szacowana jest w kołach fachowców na kilka milionów marek. Tymczasem rękopis ten dotarł drogą służbową do Głównego Urzędu Bezpieczeństwa Rzeszy. Trzeba zdecydować jeszcze dokąd przeniesione zostaną inne pozostające w skrzyni rękopisy”»8. Do Berlina wywieziono tylko Kodeks supraski. Został umieszczony pod numerem dwunastym w Zestawieniu przedmiotów wywiezionych do Rzeszy ${ }^{49}$. Co stało się z Sakramentarzem tynieckim? Czy został wywieziony do Niemiec, czy pozostał w Warszawie?

Tak naprawdę mało kto wiedział, gdzie znajduje się skrzynia z najwartościowszymi rękopisami Zamoyskich. Kommando nie wywiozło zagrabionej skrzyni do Niemiec ${ }^{50}$. Sam Paulsen wyrażał chęć, aby drogocenne kodeksy trafiły do Berlina. Tymczasem, mimo braku wiadomości o konkretnej lokalizacji Sakramentarza tynieckiego, były wobec niego różne plany. Prezydent Nadrenii chciał, aby kodeks, jako „reński zabytek kultury”, został prze-

\footnotetext{
43 Potwierdzenie odbioru rękopisów przez Wilhelma Wittego, Warszawa dnia 15 grudnia 1941, w: A. Mężyński, Kommando Paulsen, październik-grudzień 1939 r., s. 74-75.

44 Sprawozdanie Petera Paulsena, 4 I 1940, w: A. Mężyński, Kommando Paulsen, październik-grudzień 1939 r., s. $52-53$

${ }_{45}$ Notatka do akt Petera Paulsena ..., s. 73-74.

46 Notatka do akt Petera Paulsena ..., s. 74.

47 B. Horodyski, Straty działu rękopisów Biblioteki Ordynacji Zamoyskiej w latach 1939-1944, s. 330.

48 Sprawozdanie Petera Paulsena, 4I 1940, w: A. Mężyński, Kommando Paulsen, październik-grudzień 1939 r., s. 52-53.

49 Zestawienie przedmiotów wywiezionych do Rzeszy przez Kommando Paulsen, w: A. Mężyński, Kommando Paulsen, październik-grudzień 1939 r., s. 57.

50 A. Mężyński, Biblioteki Warszawy w latach 1939-1944, s. 83.
} 
kazany do Nadrenii ${ }^{1}$. Paulsen wysuwał inną propozycję, aby i Sacramentarium, i Kodeks supraski były oddane Pruskiej Bibliotece Państwowej jako stały depozyt i mogły służyć celom naukowym ${ }^{52}$.

Sakramentarz tyniecki najprawdopodobniej pozostał w Warszawie, a zaniepokojeni o jego losy bibliotekarze starali się uzyskać informacje na temat zagrabionej skrzyni. Pomoc w jej odnalezieniu zaoferował Gustav Abb, który zjawił się w Bibliotece Ordynacji Zamoyskiej 25 lipca 1940 r. i dopiero od jej pracowników dowiedział się o grabieżach, które miały tam miejsce. Wizytę tę wspomina ostatni ordynat, który przytacza słowa Gustava Abba: „To było zwykłe złodziejstwo, nie nazywam się Abb, jeżeli tych książek nie dostarczę z powrotem”53. Trzeba przyznać, że wywiązał się ze swych obietnic, chociaż nie było to łatwe zadanie. Po pierwsze musiał ustalić, kto dokonał grabieży. W liście do urzędnika Waltera von Kielpinskiego z 4 lutego I94I r. zawiadamia go o tym incydencie i prosi o pomoc w rozwiązaniu sprawy ${ }^{54}$. Do listu załącza aneks, który zawiera spis pięćdziesięciu rękopisów zagrabionych z BOZ 23 listopada I939 r. Na pierwszej pozycji umieszczony jest Missale Tinecense. Widać pewne zaangażowanie w tej sprawie, gdyż pojawia się odpowiedź na list Abba. Dokument pochodzi z 7 marca I94I r. i zawiera nieprawdziwą informację, że rękopisy Zamoyskich znajdują się w skarbcu tajnej registratury Głównego Urzędu Bezpieczeństwa Rzeszy55. W liście pada stwierdzenie, że Gubernator Generalnego Gubernatorstwa ma zamiar pokazać rękopisy Führerowi. Można z tego wnioskować, że sami Niemcy tak naprawdę nie wiedzieli, co dzieje się z zagrabionymi przez Paulsena zbiorami ${ }^{56}$. Dzięki staraniom Gustava Abba cześć zabytków została sprowadzona do BOZ w listopadzie I94I r.$^{57}$ Według relacji ordynata Jana Zamoyskiego, Abb, w grudniu tego roku, osobiście przekazał dyrektorowi Kolankowskiemu Sakramentarz tyniecki oraz Kodeks Zamoyskiego ${ }^{58}$.

\section{Akcja pruszkowska}

Po powstaniu warszawskim, na mocy umowy kapitulacyjnej z 3 października 1944 r., podpisanej przez płk. Kazimierza Iranek-Osmeckiego ${ }^{59}$ oraz SS-Obergruppenführera i generała

\footnotetext{
51 Notatka do akt Petera Paulsena ..., s. 74.

52 Tamże.

53 J. Zamoyski, „By pamięć przetrwała...”. Rozmowa z senatorem Janem Zamoyskim ..., s. 26-27.

54 Gustav Abb dyrektor Głównego Zarządu Bibliotek w Generalnym Gubernatorstwie do von Kielpinskiego urzędnika Wydziału III RSHA, Kraków dnia 4 lutego 1941, w: A. Mężyński, Kommando Paulsen, październik-grudzień 1939 r., 69-70.

55 Burmester kierownik Referatu VII A 3 RSHA do von Kielpinskiego, Berlin dnia 7.03.1941, w: A. Mężyński, Kommando Paulsen, październik-grudzień 1939 r., s. 72-73.

56 Szczegółowo poszukiwania Gustava Abba opisał Andrzej Mężyński w: Biblioteki Warszawy w latach 19391944, Warszawa 2010, s. 147-161.

57 B. Horodyski, Biblioteka Ordynacji Zamoyskiej w latach wojny, s. 21.

58 Tamże.

59 Kazimierz Wincenty Iranek-Osmecki (1897-1984), pułkownik piechoty Wojska Polskiego, w październiku 1944 r. gen. Tadeusz Komorowski wyznaczył go do prowadzenia rokowań kapitulacyjnych, 3.10.1944 r. wraz z ppłk. Zygmuntem Dobrowolskim podpisał układ o zaprzestaniu działań wojennych w Warszawie. Zob. A.K. Kunert, Stownik biograficzny konspiracji warszawskiej 1939-1944, t. 2, Warszawa 1987, s. 69-71.
} 
policji Ericha von dem Bacha-Zalewskiego ${ }^{60}$, odbyła się tak zwana akcja pruszkowska ${ }^{61}$, czyli wywożenie ocalałych zbiorów z Warszawy do hal Zakładów Remontowych w Pruszkowie ${ }^{62}$. Do gmachu bibliotecznego przetransportowano piętnaście skrzyń z cennymi kodeksami z innych bibliotek, uratowano $\mathrm{w}$ ten sposób ponad setkę rękopisów ${ }^{63}$. Bibliotekarze wyjeżdżali do Warszawy wczesnym ranem, a wracali późną nocą. Do BOZ w pierwszych dniach akcji skierowano członków grupy Biblioteki Narodowej pod kierownictwem Mariana Łodyńskiego ${ }^{64}$, który był ostatnim dyrektorem działu starych druków ${ }^{65}$. Mieli oni wywieźć tylko zbiory specjalne zawierające między innymi: dyplomy, druki z XV i XVI w., rękopisy oraz albumy ${ }^{66}$. Zbiory te umieszczono w 85 skrzyniach. Alodia Kawecka-Gryczowa ${ }^{67}$ wspomina, że w październiku 1944 r. jako pierwsze ratowano zbiory prywatne Biblioteki Ordynacji Zamoyskiej ${ }^{68}$. Przed badaczami stanął jeden $z$ najtrudniejszych wyborów: które zbiory ratować. Niemcy dali bardzo mało czasu na ewakuację. Można sobie tylko wyobrazić, co wtedy czuli odpowiedzialni za wykonanie tego zadania, jaka presja na nich ciążyła, bo przecież zdawali sobie sprawę, że to, czego nie zdołają wywieźć z Warszawy, zostanie spalone. „Z tysiąca różnych dzieł można było wybrać i dać szanse ocalenia trzem czy pięciu. Resztę przeznaczało się na zagładę"69. Wspomnienia z tej akcji są pełne opisów dramatycznych wyborów i pokazują w jak trudnych warunkach, często narażając swoje życie, bibliotekarze ratowali najcenniejsze polskie dobra kultury. Relacje tych osób zostały zebrane przez jednego z uczestników akcji, profesora Stanisława Lorentza ${ }^{70}$, w dwutomowym zbiorze pod tytułem Walka o dobra kultury. Warszawa 1939-1945. W akcji brali udział między innymi: profesor Wacław

${ }^{60}$ Erich von dem Bach-Zelewski (1899-1972), gen. SS-Obergruppenführer, w trakcie powstania warszawskiego był dowódcą oddziałów SS skierowanych do jego stłumienia. Zob. M. Dzięcielski, Pomorskie sylwetki, Toruń 2002, s. 221-233.

61 Akcją pruszkowską kierował Stanisław Lorentz, który był jednocześnie kierownikiem grupy muzealnej. Podlegali mu kierownicy zespołów archiwalnego (Witold Suchodolski) i bibliotecznego (Józef Grycz, którego zastępcą był Marian Łodyński ). Zob. A. Mężyński, Biblioteki Warszawy w latach 1939-1944, s. 264.

62 D. Matelski, Polityka Niemiec wobec polskich dóbr kultury w XX wieku, Toruń 2005, s. 150.

63 A. Kawecka-Gryczowa, Ochrona zbiorów Biblioteki Narodowej, w: Walka o dobra kultury. Warszawa 19391945, t. 1, red. S. Lorentz, s. 219.

64 Marian Łodyński (1884-1972), bibliotekarz, bibliograf, historyk. Podczas drugiej wojny światowej pracował w Bibliotece Ordynacji Krasińskich (sierpień 1940 - maj 1941) i Bibliotece Zamoyskich (lipiec 1941 - wrzesień 1944), gdzie kierował Działem Starych Druków. Zob. W. Trzebiński, K. Zieliński, Łodyński Marian Tadeusz Witold, w: Polski Stownik Biograficzny, t. 18, Wrocław 1973, s. 380-382.

65 Katalog rękopisów. Seria III. Zbiory Biblioteki Ordynacji Zamojskiej, s. 23.

66 A. Mężyński, Biblioteki Warszawy w latach 1939-1944, s. 269.

67 Alodia Kawecka-Gryczowa (1903-1990), historyk kultury, bibliotekarka, bibliolog, w lutym 1940 r. zwolniona z pracy w Bibliotece Narodowej przez władze okupacyjne, od tego czasu działała w Książnicy jako wolontariuszka - rejestrowała szkody, kopiowała katalogi, zabezpieczała kolekcje. Uczestniczyła w akcji pruszkowskiej. Zob. H. Tadeusiewicz, Alodia Kawecka-Gryczowa, w: Słownik pracowników książki polskiej, Suplement II, red. H. Tadeusiewicz, Warszawa 2000, s. 76-77.

68 A. Kawecka-Gryczowa, Ochrona zbiorów Biblioteki Narodowej, s. 226.

69 T. Makowiecki, W obronie zbiorów bibliotecznych..., s. 251.

70 Stanisław Lorentz (1899-1991), historyk sztuki, muzeolog, dyrektor Muzeum Narodowego w Warszawie w latach 1935-1982. Zob. A. Mężyński, Biblioteki Warszawy w latach 1939-1944, Warszawa 2010, s. 264. 
Borowy $^{71}$, Adam Łysakowski ${ }^{72}$, Józef Grycz, Czesław Gutry³ ${ }^{73}$ Tadeusz Makowiecki ${ }^{74}$, Marian Łodyński. Z kobiet można wymienić między innymi: Marię Wodzinowską (Dembowską)75, Alodię Kawecką-Gryczową, Irenę Łodyńską, Janinę Peszyńską.

Ocalałe zbiory z warszawskich bibliotek zapakowano do kilkudziesięciu skrzyń. Część z nich, zawierająca między innymi 85 skrzyń z księgozbiorem Zamoyskich, odjechała I5 listopada 1944 r. do Görbitsch, koło Frankfurtu nad Odrą ${ }^{76}$. We wspomnieniach Mariana Łodyńskiego znajduje się szczegółowy spis zbiorów, które znalazły się w tych skrzyniach ${ }^{77}$. Dzięki przezorności polskich bibliotekarzy nie było w nich dwóch najcenniejszych rękopisów, Sakramentarza tynieckiego i Kodeksu Zamoyskiego, które należały do „,specjalnej fory zabezpieczenia"'78. Stanisław Lorentz, dzięki temu, że kierował całą akcją pruszkowską, miał większe możliwości, nie zawsze legalne, aby pewne zabytki uchronić przed wywiezieniem do Niemiec. Tak właśnie stało się z Sakramentarzem. Podczas ewakuacji z Warszawy został osobno wywieziony przez Stanisława Lorentza do Podkowy Leśnej79. Profesor wspomina, że dyrektor biblioteki Zamoyskich, Ludwik Kolankowski, zgłosił się do niego z prośbą, aby wywiózł z Warszawy „dzieła bezcenne: tzw. Mszał tyniecki, Kronikę Galla oraz rękopis Krzyżaków Henryka Sienkiewicza i Faraona Bolesława Prusa. Szczęśliwie mi się to udało i wszystko w Podkowie Leśnej przekazałem prof. Kolankowskiemu" ". . Dyrektor przekazał je księdzu Edwardowi Kawińskiemu, który wtedy był proboszczem kolegiaty łowickiej ${ }^{81}$. O dalszych losach zabytków informuje przekaz Jana Wegnera, kuratora Muzeum w Nieborowie i Arkadii. Pamięta on, jak Kolankowski powrócił do Łowicza z kilkoma cennymi paczkami. Obydwaj panowie udali się do księdza Edwarda Kawińskiego: „,ks. Kawiński zaprowadził

\footnotetext{
71 Wacław Borowy (1890-1950), historyk literatury, krytyk literacki, w 1. 1936-1939 dyrektor Biblioteki Uniwersyteckiej w Warszawie, po powstaniu warszawskim uratował znaczną cześć zbiorów tej biblioteki. Zob. Biogramy uczonych polskich, cz. 1: Nauki spoleczne, z. 1: A-J, oprac. A. Śródka, P. Szczawiński, Wrocław 1983, s. 152-156. 72 Adam Łysakowski (1895-1952), teoretyk bibliotekoznawstwa, bibliograf. W czasie drugiej wojny światowej (grudzień 1940 - maj 1941) pracował w Bibliotece Towarzystwa Przyjaciół Nauk w Wilnie. Od stycznia 1944 r. pracował w Bibliotece Narodowej i Uniwersyteckiej, brał udział w ratowaniu warszawskich zbiorów bibliotecznych. Zob. M. Ambros, Eysakowski Adam Gracjan, w: Polski Stownik Biograficzny, t. 18, Wrocław 1973, s. 598600.

73 Czesław Gutry (1901-1990), bibliotekarz, bibliograf, pracował w bibliotece Politechniki Warszawskiej. Po upadku powstania warszawskiego brał udział w zabezpieczaniu zbiorów Biblioteki Publicznej m.st. Warszawy na Koszykowej. Zob. Cz. Gutry, Pamiętnik, w: Walka o dobra kultury. Warszawa 1939-1945, t. 2, red. S. Lorentz, s. $12-22$.

74 Makowiecki Tadeusz (1900-1952), historyk literatury i sztuki, prof. Uniwersytetu Toruńskiego. W 1. 19391945 pracował w Bibliotece Uniwersyteckiej w Warszawie, we wrześniu 1939 r. ratował zbiory ze zniszczonych gmachów uniwersytetu, od 5 listopada do 23 grudnia 1944 r współpracował przy ewakuacji dóbr kultury ze stolicy. Zob. Z. Mołodcówna, Makowiecki Tadeusz, w: Polski Stownik Biograficzny, t. 19, Wrocław 1974, s. 231-232.

75 Maria Dembowska (1914-2008), praktyk i teoretyk bibliotekarstwa, bibliografii i informacji naukowej, od 1935 r. pracowała z Bibliotece Ordynacji Zamoyskiej, w latach 1942-1944, 1945-1946, 1949-1966 w Bibliotece Narodowej. Zob. M. Dembowska, Ze wspomnień o Bibliotece Narodowej i ludziach z niq zwiqzanych, w: Wspomnienia o Bibliotece Narodowej, przedm. A. Kłossowski, Warszawa 1995, s. 159.

76 A. Mężyński, Biblioteki Warszawy w latach 1939-1944, s. 269.

77 M. Łodyński, Pruszkowska akcja zabezpieczania zbiorów bibliotecznych, w: Walka o dobra kultury. Warszawa 1939-1945, t. 2, red. S. Lorentz, s. 277-279.

78 Tamże, s. 276.

79 S. Lorentz, W muzeum i gdzie indziej, w: Walka o dobra kultury. Warszawa 1939-1945, t. 1, red. S. Lorentz, s. 99.

${ }^{80}$ Tamże, s. 99.

${ }^{81}$ Katalog rękopisów. Seria III. Zbiory Biblioteki Ordynacji Zamoyskiej, s. 23.
} 
nas do Kolegiaty i pokazał nam miejsce w nawie bocznej, gdzie pod posadzką w krypcie prymasa Jana Lipskiego ukrył przekazane mu rękopisy. Wszystko zostało umieszczone [...] w dużej puszce z blachy cynkowej i osobiście zalutowanej przez niego" ${ }^{\text {"2. }}$. Sakramentarz i Kodeks w 1947 r. znalazły się z powrotem w Warszawie.

\section{Zakończenie}

Sumując wojenne zniszczenia, Biblioteka Ordynacji Zamoyskiej największe straty poniosła już na początku, we wrześniu I939 roku, oraz podczas powstania warszawskiego, w sierpniu i w październiku $1944 \mathrm{r}^{83}$. Znaczne straty przyniosła także tak zwana akcja pruszkowska, czyli wywożenie zbiorów ze stolicy. Szacuje się, że biblioteka utraciła wtedy około $84 \%$ przedwojennego księgozbioru ${ }^{84}$. Część ocalałych zbiorów, w tym Sakramentarz tyniecki, została zdeponowana przez szesnastego ordynata w Bibliotece Narodowej ${ }^{85}$. Były one traktowane jako depozyt aż do 1952 r., kiedy to stały się własnością Biblioteki Narodowej w związku z ustawą sejmową, która znosiła fundacje, w tym także biblioteki fundacyjne ${ }^{86}$. W latach 1950-1958 rękopisy z biblioteki Zamoyskich zostały podzielone, część pozostała w zbiorach Biblioteki Narodowej, gdzie stanowi osobną grupę z zachowanymi oryginalnymi

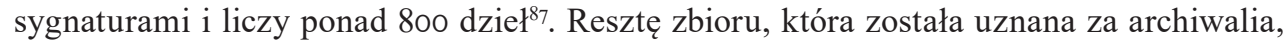
przekazano do archiwów państwowych. Sakramentarz tyniecki jest dziś częścią księgozbioru Biblioteki Narodowej.

Sakramentarz tyniecki to jeden z najstarszych przechowywanych w Polsce rękopiśmiennych kodeksów, warto pamiętać o jego losach, pokazują one bowiem, jak książka wpisała się w kulturę narodu i jego tożsamości. Z uwagi na fakt, że polska kultura poniosła ogromne starty podczas ostatniej wojny, szczególnie cieszą uratowane zbiory. Nie zachowało się wiele cennych rękopisów, dlatego możliwość posiadania chociaż kilku zabytków powinna napawać dumą i szczególną odpowiedzialnością wiążącą się z dbałością nie tylko o ich obecny stan, chociaż to jest także bardzo ważne, ale przypomnieniem ich nieraz trudnych losów, kiedy często było o krok od utracenia ich na zawsze.

Trudno sobie wyobrazić polską kulturę bez Kazań świętokrzyskich, Psalterza floriańskiego, Biblii Gutenberga czy właśnie Sakramentarza tynieckiego. Na przykładzie historii tego ostatniego i działań, w których tak bardzo zabiegano o odzyskanie rękopisu, można doskonale zobaczyć, jak wiele dla kultury znaczy chociaż jeden średniowieczny zabytek. Zgłębiając losy Sakramentarza przez te wszystkie stulecia, można się dziwić, że zachował się do czasów współczesnych. W Polsce podobną drogę, jak opisany Sakramentarz tyniecki, przeszły prawie wszystkie zabytki. Mimo starań bibliotekarzy, naukowców, ale także ludzi niezwiązanych z pracą biblioteczną, nie udało się uratować wszystkich przedwojennych zbiorów. Polska straciła ogromną liczbę bezcennych magnackich i kościelnych księgozbiorów.

\footnotetext{
82 S. Lorentz, W muzeum i gdzie indziej, s. 100.

83 H. Łaskarzewska, Bogdan Horodyski - kronikarz dziejów Biblioteki Ordynacji Zamoyskiej w czasie okupacji (1939-1945), s. 5.

84 Tamże.

85 Tamże, s. 9.

${ }^{86}$ Katalog rękopisów. Seria III. Zbiory Biblioteki Ordynacji Zamojskiej, s. 7.

87 Tamże.
} 
Dlatego ważne jest pochylanie się nad tymi kilkoma ocalałymi zabytkami, zwłaszcza tak unikatowymi jak Sakramentarz tyniecki.

\section{The history of the Sacramentorium Tynecensis during the World War II Summary}

The SacramentoriumTynecensis was written in circa I060-I070, probably in Cologne. It was located in the Benedictine Abbey in Tyniec from IIth century to I9th century. In I8I4 the illuminated manuscript was bought by Stanisław Kostka Zamoyski, then in I8I8 he located the codex in the Zamoyski Ordynacja Library in Warsaw. It stayed there to the end of World War II. Two formations of Nazi Germany were as follows: a military unit led by Professor of Archaeology, Peter Paulsen and a group led by art historian Kajetan Mühlman. Both were responsible for the plundering of Poland's cultural heritage. They wanted to get the Sacramentorium Tynecensis because it was connected with German culture. The employees of the Zamoyski Ordynacja Library have tried to rescue the codex, sometimes at the risk of their own lives. In I944 during the action of rescuing library collections from the ruins of the capital city of Poland (action called 'Pruszkowska'), the manuscript codex was exported and hidden by Stanisław Lorentz in the Cathedral in Łowicz. Thankfully that the Sacramentorium Tynecensis returned to Warsaw in 1947 and was deposited in the National Library of Poland.

Keywords: SacramentoriumTynecensis, manuscript codex, World War II, the Zamoyski Ordynacja Library, struggle for cultural heritage

\section{BIBLIOGRAFIA}

Źródła drukowane

Burmester kierownik Referatu VII A 3 RSHA do von Kielpinskiego, Berlin dnia 7.03.I94I, w: A. Mężyński, Kommando Paulsen: październik-grudzień 1939 r., Warszawa I994, S. 72-73.

Dembowska M., Ze wspomnień o Bibliotece Narodowej i ludziach z nią związanych, w: Wspomnienia o Bibliotece Narodowej, przedm. A. Kłossowski, Warszawa I995, s. I59-I93.

Grycz J., Polityka hitlerowska w ,Generalgouvernement”, w: Walka o dobra kultury. Warszawa 1939-1945, t. I, red. S. Lorentz, Warszawa I970, s. 248-257.

Gustav Abb dyrektor Głównego Zarzadu Bibliotek w Generalnym Gubernatorstwie do von Kielpinskiego urzędnika Wydziału III RSHA, Kraków dnia 4 lutego I94I, w: A. Mężyński, Kommando Paulsen: październik-grudzień 1939 r., Warszawa I994, s. 69-7I.

Gutry Cz., Pamiętnik, w: Walka o dobra kultury. Warszawa 1939-I945, t. 2, red. S. Lorentz, Warszawa 1970, s. I2-22.

Kawecka-Gryczowa A., Ochrona zbiorów Biblioteki Narodowej, w: Walka o dobra kultury. Warszawa I939-1945, t. I, red. S. Lorentz, Warszawa 1970, S. I79-242.

Lorentz S., W muzeum i gdzie indziej, w: Walka o dobra kultury. Warszawa I939-I945, t. I, red. S. Lorentz, Warszawa I970, s. I3-IIO.

Łodyński M., Pruszkowska akcja zabezpieczania warszawskich zbiorów bibliotecznych, w: Walka o dobra kultury. Warszawa 1939-I945, t. 2, red. S. Lorentz, Warszawa I970, s. $266-285$. 
Makowiecki T., W obronie zbiorów bibliotecznych, w: Walka o dobra kultury. Warszawa I939-I945, t. 2, red. S. Lorentz, Warszawa 1970, s. 244-266.

Notatka do akt Petera Paulsena [Dotyczy: Zbioru rękopisów z Biblioteki Zamoyskich w Warszawie] Berlin, dnia I8 kwietnia I94I, w: A. Mężyński, Kommando Paulsen: październik-grudzień 1939 r., Warszawa 1994, s. 73-74.

Potwierdzenie odbioru rękopisów przez Wilhelma Wittego, Warszawa dnia I5 grudnia I94I, w: A. Mężyński, Kommando Paulsen: październik-grudzień 1939 r., Warszawa 1994, s. $74-75$.

Sprawozdanie Petera Paulsena, 4 I I940, w: A. Mężyński, Kommando Paulsen: październik-grudzień 1939 r., Warszawa 1994, s. 48-55.

Zestawienie przedmiotów wywiezionych do Rzeszy przez Kommando Paulsen, w: A. Mężyński, Kommando Paulsen: październik-grudzień 1939 r., Warszawa 1994, s. 56-57.

Opracowania

Ambros M., Eysakowski Adam Gracjan (I895-I952), w: Polski Stownik Biograficzny, t. I8, Wrocław 1973, s. 598-600.

Biblioteka Ordynacji Zamoyskiej: od Jana do Jana. Przewodnik po wystawie, oprac. T. Makowski, Warszawa 2005.

Biogramy uczonych polskich, cz. I: Nauki społeczne, z. I: A-J, oprac. A. Śródka, P. Szczawiński, Wrocław 1983.

Boguniowski J.W., Rozwój historyczny ksiąg liturgii rzymskiej do Soboru Trydenckiego i ich recepcja w Polsce, Kraków 200I.

Długosz J., Kolankowski Ludwik, w: Stownik Pracowników Ksiązki Polskiej, red. I. Treichel, Warszawa-Łódź 1972, s. 428.

Dzięcielski M., Pomorskie sylwetki, Toruń 2002.

Horodyski B., Biblioteka Ordynacji Zamoyskiej w latach wojny, Warszawa 2005.

Horodyski B., Straty dziatu rękopisów Biblioteki Ordynacji Zamoyskiej w latach 1939-I944, w: Straty bibliotek i archiwów warszawskich w zakresie rękopiśmiennych źródet historycznych, t. 3, red. P. Bańkowski, Warszawa 1955, s. 319-374.

Horodyski B., Zarys dziejów Biblioteki Ordynacji Zamoyskich, w: Studia nad książka poświęcone pamięci Kazimierza Piekarskiego, red. K. Budzyk, A. Kawecka-Gryczowa, Wrocław 195I, s. 295-34I.

Katalog rękopisów. Seria III. Zbiory Biblioteki Ordynacji Zamoyskiej, t. II, oprac. B. Smoleńska, K. Muszyńska, Warszawa I99I.

Katalog Wystawy Rękopisów i druków wywiezionych przez hitlerowców do Niemiec uratowanych przez Armię Czerwona i przekazanych Polsce przez rząd radziecki, przedm. S. Skrzeszewski, Warszawa 1948.

Konopczyński W., Korzon Tadeusz Sylwester (I839-I9I8), w: Polski Stownik Biograficzny, t. I4, Wrocław I968-I969, s. I78-I8I.

Kunert A.K., Kazimierz Wincenty Iranek-Osmecki, w: Stownik biograficzny konspiracji warszawskiej 1939-I944, t. 2, Warszawa 1987, s. 69-7I.

Lewak A., Archiwa i biblioteki Warszawy podczas wojny i okupacji w latach 1939-I945, w: Walka o oświatę, naukę i kulturę w latach okupacji 1939-I944. Materiaty z terenu m.st. Warszawy $i$ woj. warszawskiego, oprac. S. Dobraniecki, W. Pokora, Warszawa I967, s. 680-728. 
Łaskarzewska H., Biblioteki warszawskie w latach okupacji. Zasady działania, straty księgozbiorów, w: Straty Warszawy 1939-I945. Raport, red. W. Fałkowski, Warszawa 2005, S. $535-563$.

Łaskarzewska H., Bogdan Horodyski - kronikarz dziejów Biblioteki Ordynacji Zamoyskiej w czasie okupacji (I939-I945), w: B. Horodyski, Biblioteka Ordynacji Zamoyskiej w latach wojny, Warszawa 2005, s. 5-23.

Matelski D., Polityka Niemiec wobec polskich dóbr kultury w XX wieku, Toruń 2005.

Mężyński A., Biblioteki Warszawy w latach I939-I945, Warszawa 2010.

Mężyński A., Kommando Paulsen, październik-grudzień 1939 r., Warszawa 1994.

Michalewska A., Walendowska A., Horodyski Bogdan, w: Słownik Pracowników Książi Polskiej, red. I. Treichel, Warszawa-Łódź 1972, s. 340-34I.

Mołodcówna Z., Makowiecki Tadeusz (I90o-I952), w: Polski Słownik Biograficzny, t. I9, Wrocław I974, s. 23I-232.

Podlacha W., Historia malarstwa w Polsce, t. I: Od średniowiecza do wieku XVIII-go, cz. I: Malarstwo średniowieczne, Lwów I9I3.

Potkowski E., Książka rękopiśmienna w kulturze Polski, Warszawa 1984.

Tadeusiewicz H., Alodia Kawecka-Gryczowa, w: Słownik pracowników książki polskiej, Suplement II, red. H. Tadeusiewicz, Warszawa 2000, s. 76-77.

Trzebiński W., Zieliński K., Łodyński Marian Tadeusz Witold (I884-I972), w: Polski Stownik Biograficzny, t. I8, Wrocław I973, s. 380-382.

Więckowska H., Treichel I., Grycz Józef (I890-I954), w: Polski Słownik Biograficzny, t. 9, Wrocław I960-I96I, s. 69-7I.

Wspomnienia o Bibliotece Narodowej, przedm. A. Kłossowski, Warszawa 1995.

Zamoyski J., „By pamięć przetrwała...”. Rozmowa z senatorem Janem Zamoyskim XVI ordynatem Zamoyskim. Rozmawiała E. Markiewicz, „Biuletyn Informacyjny Biblioteki Narodowej", I999, nr 2, s. 26-27. 